\title{
Igbp1 is part of a positive feedback loop in stem cell factor-dependent, selective mRNA translation initiation inhibiting erythroid differentiation
}

\author{
Godfrey Grech, ${ }^{1}$ Montserrat Blázquez-Domingo, ${ }^{1}$ Andrea Kolbus, ${ }^{2,3}$ Walbert J. Bakker, ${ }^{1}$ Ernst W. Müllner, ${ }^{4}$ Hartmut Beug, ${ }^{2}$ \\ and Marieke von Lindern ${ }^{1}$ \\ 1Department of Hematology, Erasmus Medical Centre, Rotterdam, The Netherlands; ${ }^{2}$ Research Institute of Molecular Pathology, Vienna, Austria; and \\ ${ }^{3}$ Department of Obstetrics and Gynecology and ${ }^{4}$ Max F. Perutz Laboratories, Department of Medical Biochemistry, Medical University of Vienna, Vienna, Austria
}

\begin{abstract}
Stem cell factor (SCF)-induced activation of phosphoinositide-3-kinase (PI3K) is required for transient amplification of the erythroblast compartment. PI3K stimulates the activation of mTOR (target of rapamycin) and subsequent release of the cap-binding translation initiation factor $4 E$ (elF4E) from the 4E-binding protein 4EBP, which controls the recruitment of structured mRNAs to polysomes. Enhanced expression of elF4E renders proliferation of erythroblasts independent of PI3K. To investigate which mRNAs are selectively recruited to polysomes, we
\end{abstract}

compared SCF-dependent gene expression between total and polysome-bound mRNA. This identified 111 genes primarily subject to translational regulation. For 8 of 9 genes studied in more detail, the SCF-induced polysome recruitment of transcripts exceeded 5-fold regulation and was PI3K-dependent and elF4E-sensitive, whereas total mRNA was not affected by signal transduction. One of the targets, Immunoglobulin binding protein 1 (Igbp1), is a regulatory subunit of protein phosphatase 2A (Pp2a) sustaining mTOR signaling. Constitutive expression of Igbp1 impaired erythroid differentiation, maintained 4EBP and p70S6k phosphorylation, and enhanced polysome recruitment of multiple elF4E-sensitive mRNAs. Thus, PI3K-dependent polysome recruitment of Igbp1 acts as a positive feedback mechanism on translation initiation underscoring the important regulatory role of selective mRNA recruitment to polysomes in the balance between proliferation and maturation of erythroblasts. (Blood. 2008; 112:2750-2760)

\section{Introduction}

The balance between expansion and differentiation of hematopoietic progenitor compartments is controlled by cytokines and growth factors. In erythropoiesis, stem cell factor (SCF), the ligand for cKit, cooperates with glucocorticoids and erythropoietin (Epo) to suppress differentiation and sustain renewal divisions of erythroblasts in vitro $^{1,2}$ as well as in vivo. ${ }^{3,4}$ Activation of phosphotidylinositol-3 kinase (PI3K) is essential for proliferation of erythroblasts. ${ }^{2,5-8}$ Activated PI3K generates PIP3, which serves as an anchor for multiple $\mathrm{PH}$-domain-containing proteins, such as protein kinase $\mathrm{B}$ (PKB). Although both Epo and SCF induce activation of PI3K in erythroblasts, the efficiency with which respective downstream signaling pathways are activated shows large differences. ${ }^{9,10}$ In cultured erythroblasts, the activation of $\mathrm{PKB}$ is much more responsive to SCF compared with Epo. PKB activates mammalian target of rapamycin (mTOR) through phosphorylation of the tumor suppressor complex Tsc1/Tsc2 (tuberous sclerosis protein), which releases RAS homolog enriched in brain (Rheb) to phosphorylate mTOR. ${ }^{11,12}$ Activation of mTOR results in phosphorylation and activation of p70S6 kinase (Rps6kb1) ${ }^{13}$ and hierarchical phosphorylation of 4E-binding protein (4EBP), ${ }^{14,15}$ resulting in release of the mRNA cap-binding factor eukaryotic initiation factor 4E (eIF4E). ${ }^{16}$ Subsequently, eIF4E can bind the scaffold protein eIF4G to the site otherwise occupied by $4 \mathrm{EBP}$, which enables the formation of an eIF4F-scanning complex containing eIF4E, eIF4G, and the RNA helicase eIF4A. ${ }^{17}$ eIF4F associates with several other translation factor complexes, includ- ing eIF3, eIF2, and the ribosomal subunits. ${ }^{18}$ This complex scans the 5'UTR for the first AUG codon in an appropriate sequence context to start protein synthesis. ${ }^{19}$ eIF4E is the rate-limiting factor in the scanning process, ${ }^{20,21}$ and its release on phosphorylation of $4 \mathrm{EBP}$ is a crucial control mechanism in the recruitment of mRNAs to polysomes. Importantly, transcripts with a short and simple 5'UTR show a limited sensitivity to 4EBP phosphorylation, whereas transcripts with a long and structured $5^{\prime}$ UTR or with a terminal oligopyrimidine tract (TOP) are highly sensitive to the concentration of eIF4F complexes in the cell. ${ }^{19,22,23}$

The mechanism by which mTOR controls 4EBP phosphorylation involves regulation of 4EBP-phosphorylation but also regulation of the serine/threonine phosphatase $\mathrm{Pp} 2 \mathrm{a},{ }^{24-27}$ which can dephosphorylate p70S6K and 4EBP, thereby suppressing translation initiation. Pp2a exists in various complexes that shift target specificity depending on the binding of regulatory components. Binding of the $\alpha 4$ subunit (designated immunoglobulin binding protein 1 [Igbp1]) to the Pp2a catalytic subunit modifies Pp2a phosphatase activity. mTOR stimulates the formation of the Pp2a- $\alpha 4$ complex, which was shown to sequester the phosphatase activity away from its own downstream targets 4EBP and p70S6 kinase. ${ }^{26,28}$ The effects of Pp2a- $\alpha 4$ complex formation, however, may be context dependent, ${ }^{29}$ and $\operatorname{Igbp} 1(\alpha 4)$ has additional functions, for instance, in stabilizing the interaction of the midline complex with microtubules. ${ }^{30}$
Submitted January 10, 2008; accepted June 4, 2008. Prepublished online as Blood First Edition paper, July 14, 2008; DOI 10.1182/blood-2008-01-133140.

The online version of this article contains a data supplement.
The publication costs of this article were defrayed in part by page charge payment. Therefore, and solely to indicate this fact, this article is hereby marked "advertisement" in accordance with 18 USC section 1734.

(C) 2008 by The American Society of Hematology 
We showed that 4EBP is potently phosphorylated by $\mathrm{SCF},{ }^{10}$ and described 3 transcripts that require SCF-induced PI3K/mTOR activation to be recruited to polysomes, whereas SCF does not affect their transcript levels. ${ }^{10}$ We also demonstrated that overexpression of eIF4E increased the levels of eIF4F complexes and suppressed erythroid differentiation in the absence of SCF. Thus, mechanisms that control eIF4F formation are important to regulate the balance between expansion and differentiation in erythropoiesis, ${ }^{10}$ in line with reports stating that overexpression of eIF4E in tumor samples is associated with increased malignancy. ${ }^{31-34}$ Apparently, selective mRNA translation plays a major role in erythropoiesis, but knowledge on mRNAs subject to factor-dependent polysome recruitment remained scarce.

In this study, we compared factor-dependent mRNA expression in total and polysome-bound (pb) mRNA and identified 111 transcripts that require PI3K or increased eIF4F levels for polysome recruitment. From these we selected 9 genes suspected to be involved in signal transduction or gene expression and analyzed their expression regulation and biologic function in erythroblasts. Except for one gene that was regulated by both gene transcription and mRNA translation, the selected genes were strictly regulated by polysome recruitment in response to SCF-induced activation of PI3K and eIF4F formation. Strikingly, we identified the Pp2aassociated protein Igbp1 ( $\alpha 4$ subunit of Pp2a) as a target of SCF-dependent polysome recruitment. Constitutive expression of Igbp1 in erythroblasts enhanced the mTOR-dependent phosphorylation of S6K and 4EBP. Exogenous Igbp1 strongly impaired differentiation of erythroblasts and enhanced polysome recruitment of other target gene mRNAs identified in this screen.

\section{Methods}

\section{Cell culture}

I/11 cells were cultivated in StemPro-34 (Invitrogen, Breda, The Netherlands). ${ }^{2}$ For expansion, the medium was supplemented with $0.5 \mathrm{U} / \mathrm{mL}$ of Epo, (kind gift from Ortho Biotech Products, Tilburg, The Netherlands), $100 \mathrm{ng} / \mathrm{mL}$ of SCF (supernatant of CHO producer cells), and $10^{-6} \mathrm{M}$ of dexametasone (Dex; Sigma-Aldrich, St Louis, MO). To induce differentiation, cells were cultivated in StemPro-34 supplemented with $5 \mathrm{U} / \mathrm{mL}$ of Epo and $0.5 \mathrm{mg} / \mathrm{mL}$ of iron-loaded transferrin (Scipac, Sittingbourne, United Kingdom). Cell numbers and cell size distribution were determined using an electronic cell counter (CASY-1; Schärfe-System, Reutlingen, Germany). LY294002 (10 $\mu \mathrm{M}$ in final volume) and rapamycin $(40 \mathrm{ng} / \mathrm{mL})$ were obtained from Alexis (Lausen, Switzerland); actinomycin D (10 $\mu \mathrm{g} /$ $\mathrm{mL})$ and cycloheximide $(50 \mu \mathrm{g} / \mathrm{mL})$ were from Sigma-Aldrich.

\section{Hemoglobin content and cell morphology}

Small aliquots of the cultures were removed and analyzed for hemoglobin content by photometry as described. ${ }^{9,35}$ Cell morphology was analyzed in cytospins stained with histologic dyes and neutral benzidine, ${ }^{36}$ using an OlympusBX40 microscope (40× objective, NA 0.65), an OlympusDp50 CCD camera, and Viewfinder Lite 1.0 acquisition software. Images were cropped using Adobe Photoshop version 6.0 (Adobe Systems, Mountain View, CA).

\section{Microarray hybridization and analysis}

A MIAME-compatible description of sample preparation and hybridization protocols is given in Document S1 (available on the Blood website; see the Supplemental Materials link at the top of the online article). Microarray data were analyzed using the Rosetta Resolver system, as described. ${ }^{37}$ All microarray data have been deposited at http://www.ebi.ac.uk/microarray-as/ ae/browse.html?keywords=E-MEXP-1689.

\section{Sodium dodecyl sulfate-polyacrylamide gel electrophoresis, Western blotting, and antibodies}

For acute stimulation with growth factors, proliferating I/11 cells were washed twice with phosphate-buffered saline (PBS) and seeded at $4 \times 10^{6} \mathrm{cells} / \mathrm{mL}$ in plain Iscove modified Dulbecco medium (IMDM, Invitrogen). After 4 hours of factor deprivation, cells were stimulated at $37^{\circ} \mathrm{C}$ with SCF $(100 \mathrm{ng} / \mathrm{mL})$ or Epo $(5 \mathrm{U} / \mathrm{mL})$. Cells were harvested by addition of ice-cold PBS. Cell lysates, sodium dodecyl sulfatepolyacrylamide gel electrophoresis (SDS-PAGE), immunoprecipitation, and Western blotting were performed as described ${ }^{38} ; 10 \mu \mathrm{L}$ of protein extract $\left(1 \times 10^{6}\right.$ cells $)$ was loaded onto a $15 \%$ polyacrylamide gel. The antibodies used were $\alpha$-4EBP1 (Cell Signaling Technology, Danvers, MA), $\alpha$-Uhmk1 (gift from M. Boehm, National Institutes of Health/National Heart, Lung, and Blood Institute), $\alpha$-Igbp1 (gift from D. L. Brautigan, Center for Cell Signaling, University of Virginia, Charlotesville), S6K-P (Cell Signaling Technology), and $\alpha$-Fli1 and $\alpha$-Myc (Santa Cruz Biotechnology, Santa Cruz, CA).

\section{Transduction of $\mathrm{l} / 11$ clones}

The coding sequences of selected genes were amplified from cDNA derived of I/11 cells using Pfu polymerase (M7741; Promega, Leiden, The Netherlands) and primers designed to insert an EcoRI at the $5^{\prime}$ end and a ClaI site at the $3^{\prime}$ end of the polymerase chain reaction (PCR) product (Table S4). The PCR product was inserted in TA vector (KNM2040-01; Invitrogen); subsequently, the EcoRI/ClaI fragment was transferred to a pBlueScript vector. The PCR primer inserted the ATG of the coding sequence in frame to a 6-myc-tag sequence at the EcoRI site of the pBlueScript vector. Next, a BamHI/SalI fragment containing the N-terminal myc-tag and the coding sequence was inserted into the retroviral expression vector $\mathrm{pBabe}$. Retroviral transduction was performed as described. ${ }^{9}$

\section{RNA isolation and cDNA synthesis for PCR}

Isolation of polysomal RNA by sucrose gradient fractionation was performed as described. ${ }^{10,39}$ Total RNA was isolated by the same protocol, omitting the density centrifugation. Cell extracts were layered on a 4-mL linear sucrose gradient (15\%-40\% sucrose $\mathrm{wt} / \mathrm{vol})$, and 8 fractions were collected. Northern blotting indicated that fractions 1 to 4 contain nonpolysomal and subpolysomal mRNA, whereas fractions 5 to 8 consisted of pb RNA. These fractions were pooled to generate subpolysomal and polysomal mRNA of each sample. RNA was quantified by UV-absorbance. Poly $(\mathrm{A})^{+}$mRNA was purified and cDNA was generated as described. ${ }^{39}$

\section{Real-time PCR}

Real-time PCR was performed using SYBR green and a Taqman PCR machine (model 7700 sequence detector, Applied Biosystems, Foster City, CA) ${ }^{40}$ The amplification program started with 2 minutes at $50^{\circ} \mathrm{C}$ (AmpErase UNG incubation), 10 minutes at $95^{\circ} \mathrm{C}$ (AmpliTaq Gold Activation), followed by 40 cycles of 15 seconds' denaturation at $95^{\circ} \mathrm{C}, 30$ seconds of annealing at $62^{\circ} \mathrm{C}$, and 30 seconds' of extension at $72^{\circ} \mathrm{C}$. All primer pairs had similar PCR annealing temperatures. To confirm amplification specificity, the dissociation curve was checked at the end of each run, and PCR products from each primer pair were checked by gel electrophoresis. Gene-specific primers are listed in Table S5 and were obtained from Invitrogen or Sigma-Genosys (The Woodlands, TX).

\section{Results}

\section{Transcripts dependent on Epo/SCF induced polysome recruitment}

To identify mRNA transcripts that are selectively recruited to polysomes on growth factor stimulation of erythroblasts, we compared factor-induced gene expression at the level of total and pb RNA using mRNA profiling. We used immortalized $p 53^{-/-}$ 
A

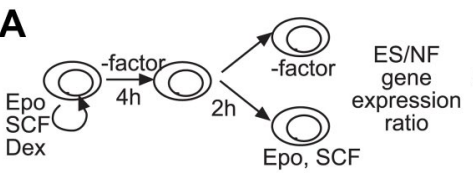

B

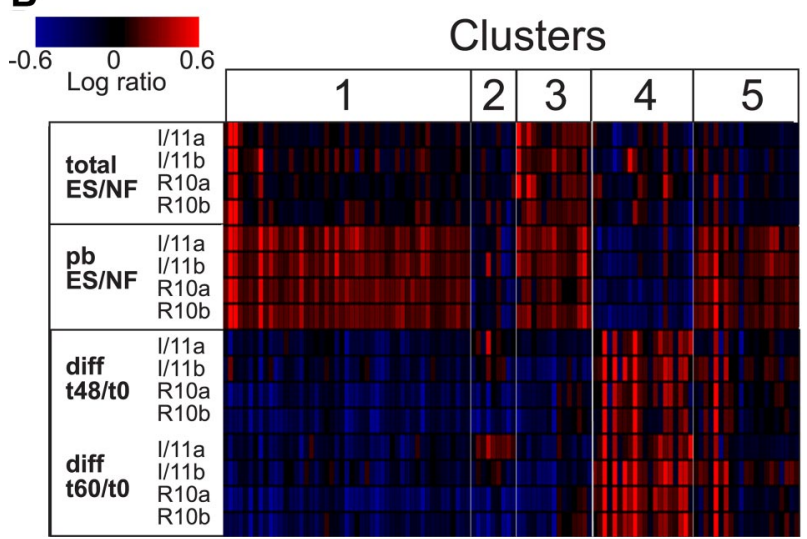

Figure 1. Cluster analysis of genes subject to regulation by Epo/SCF-controlled mRNA polysome recruitment and their regulation during differentiation. $(A, B)$ Cells from the I/11 and R10 line were factor-deprived for 4 hours and stimulated with Epo plus SCF (ES) or left untreated (NF) for 2 hours. Total RNA and polysome-bound (pb) mRNA were isolated and used for RNA profiling on MG_U74Av2 Affymetrix oligonucleotide arrays. For each of 2 biologically independent experiments (I/11a and I/11b; R10a and R10b), the ES/NF ratio of intensity data was calculated. Significant variance between ES/NF ratios obtained with total and pb RNA was calculated using ANOVA $(P=.01)$. In addition, differential expression in at least 2 single experiments had to be significant $(P=.001)$. This selection yielded 115 probe sets. For these genes, the expression ratios after 48- or 60-hour differentiation induction were calculated compared with proliferation conditions (diff t48/t0 and t60/t0). Expression ratios were clustered using Rosetta software and Pearson correlation. Bar (top left corner) represents correlation of up- and downregulation with the intensity of red and blue, respectively, on a log-10 scale.

erythroblasts having a lifespan that allows analysis on large numbers of cells while closely resembling primary progenitors. ${ }^{1}$ The lack of p53 will make a difference, for instance, in response to DNA damage, but not in response to mitogenic factors. Erythroblasts were factor-deprived (4 hours) and restimulated ( 2 hours) with Epo plus SCF, or left unstimulated. Four independently generated replicates were prepared from 2 established $p 53^{-/-}$ erythroblast cultures with different genetic background (I/11 and R10). ${ }^{2,41}$ Total and pb RNA were isolated twice from each culture, cRNA was generated and hybridized to Affymetrix oligonucleotide arrays. Rosetta Resolver software was used to normalize and analyze the intensity data as described ${ }^{37}$; samples are described in Table S1. The ratio of gene expression in Epo/SCF stimulated samples (ES) versus factor-deprived cells (NF) was calculated for total and pb mRNA (Figure 1A). Next, we applied a 2-step selection to identify genes differentially regulated in total versus $\mathrm{pb}$ RNA. First, genes with sufficient variance between the ES/NF ratios for total and pb RNA were selected by analysis of variance $(P=.01)$. Second, selected genes had to be differentially expressed in presence or absence of Epo/SCF in total or pb mRNA in either both $\mathrm{I} / 11$ or in both $\mathrm{R} 10$ hybridizations $(P=.001$; for details on this strategy, see Document S1). This approach selected 115 probe sets representing 111 different transcripts subject to Epo/SCF-controlled polysome recruitment (Table S5). To relate differential polysome recruitment to gene expression during differentiation, we derived pb mRNA from steady-state expanding and differentiating erythroblasts (48 and 60 hours after differentiation induction; again, 4 independent replicates). After hybridization of oligonucleotide arrays, the gene expression ratio of differentiation over steady-state renewal was calculated. Subsequent cluster analysis of gene expression ratios of the 115 selected probe sets resulted in a matrix that groups the selected probe sets into 5 separate clusters based on Epo/SCF-controlled gene expression detected in total and pb RNA and on expression during differentiation (Figure 1B; Table S5).

Genes represented in clusters 1, 3, and 5 (83 genes) were subject to Epo/SCF-induced polysome recruitment; clusters 1 and 3 were also characterized by decreased expression during differentiation. To gain further insight into regulation of gene expression in the various clusters, we compared normalized intensity data obtained from the array hybridization with total and $\mathrm{pb}$ RNA from factor-deprived and Epo/SCF-restimulated cells (Figure S1). Cluster 1 represents genes with constitutive expression in total RNA and Epo/SCF-induced polysome recruitment. Cluster 3 represents genes of which transcription is increased by growth factor stimulation, but polysome recruitment shows a more pronounced increase in response to Epo/ SCF. Cluster 5 represents genes characterized by Epo/SCFinduced repression of expression in total mRNA, but with maintained levels in pb RNA, which implies increased Epo/SCFinduced polysome recruitment from a smaller transcript pool. Genes present in clusters 2 and 4 are subject to enhanced polysome recruitment after factor deprivation, which is abrogated by Epo/SCF restimulation (Figure S1). These genes may play a role in the initiation of stress responses. Only genes represented by cluster 4 were up-regulated during differentiation.

\section{Polysome recruitment of selected transcripts depends on the PI3K/mTOR/elF4E pathway}

Next, 9 genes were selected that (1) require Epo/SCF for polysome recruitment, (2) are down-regulated in differentiation, (3) are suggested to function in signal transduction or control of gene expression, and (4) were hitherto not known to be translationally regulated (Table 1; for details on these genes, see Table S2). Quantitative reverse-transcribed PCR (Q-PCR) was used to analyze whether polysome recruitment was dependent on PI3K and mTOR, and on eIF4E expression.

First, we tested how signal-dependent expression in total and $\mathrm{pb}$ RNA correlates between array data and Q-PCR. We determined transcript levels in subpolysomal and pb RNA by Q-PCR and calculated the percentage polysome recruitment. In addition to the 9 selected genes, Nm23-M2 (Nme2) and Ybxl were tested as positive controls. ${ }^{10}$ A control gene, Fli-1, that is not regulated at the level of RNA-specific polysome recruitment, showed at most a 2-fold difference in polysome recruitment in response to Epo or SCF (Table 1; Figure 2C,F). In contrast, Nme2, $Y b x 1$, and 8 of 9 of the selected genes showed a 10-fold increase or more in polysome recruitment in response to Epo plus SCF; only Grwdl failed to reproduce the regulation detected on the arrays (Table 1; Figure 2A,B,D,E). The SCF-induced increase in polysome recruitment exceeded Epo-induced polysome recruitment, whereas Epo plus SCF showed an additive or even synergistic effect (Table 1, Figure 2D,E). Cluster 1 genes Igbp1, mEd2, Rnf138, Nap1l1, and Cnih, cluster 3 gene Nubpl, and cluster 5 gene $U h m k 1$ were almost exclusively up-regulated in pb but hardly in total mRNA (Table 1); cluster 5 gene Hnrpal was down-regulated in total mRNA in accordance with the array data (Tables 1 and S5). Inhibition of PI3K (LY294002) or mTOR (rapamycin) decreased polysome recruitment of the control gene Fli-1 approximately 2-fold but completely dissociated all other genes from polysomes (Table 1 ; Figure 2D-F). 
From www.bloodjournal.org at Erasmus MC Medical Library on August 4, 2009. For personal use only.

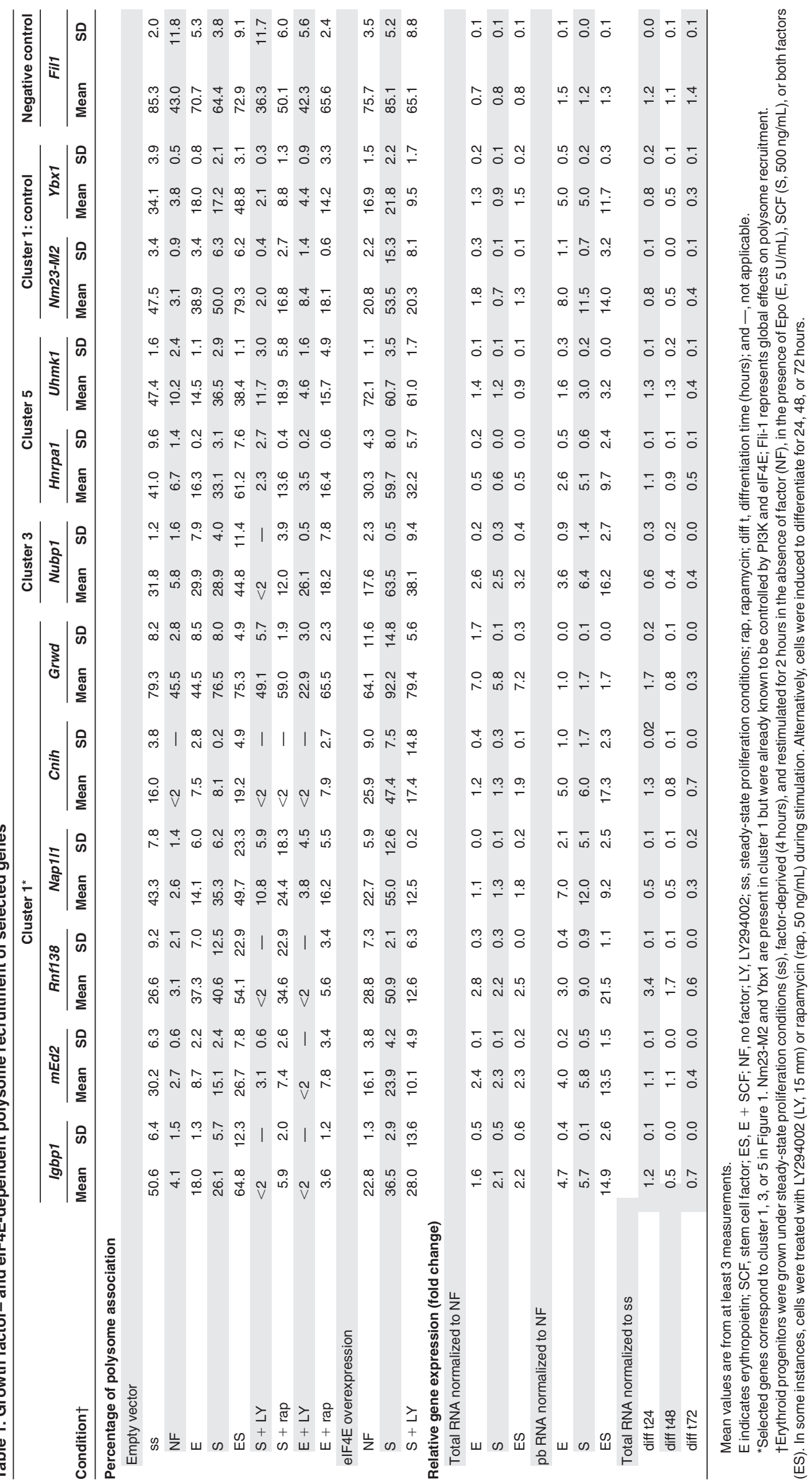



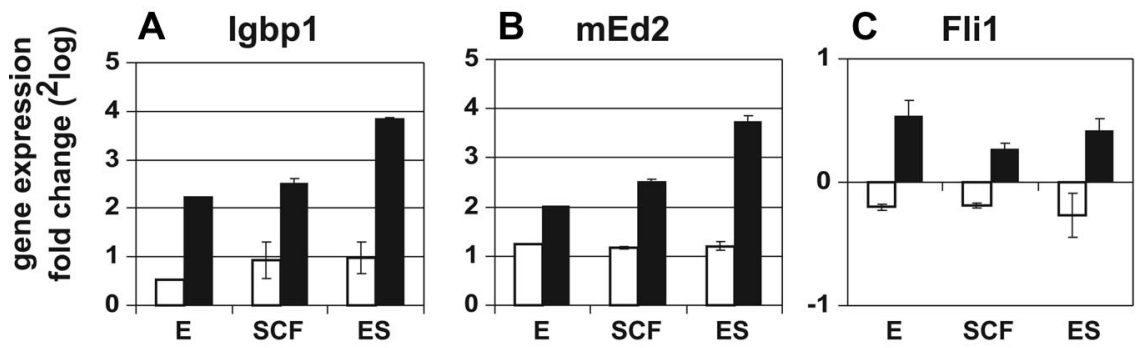

Figure 2. Polysome recruitment of Igbp 1 and $m E d 2$ is PI3K and elF4E sensitive. 1/11 cells were factordeprived for 4 hours and subsequently restimulated with Epo $(E, 2 \mathrm{U} / \mathrm{mL})$, SCF $(\mathrm{S}, 100 \mathrm{ng} / \mathrm{mL})$, or both (ES) for 2 hours. Where indicated, LY294002 (LY; $10 \mu \mathrm{M})$ or rapamycin $(\mathrm{R} ; 10 \mathrm{nM})$ was added 30 minutes before and during restimulation. Total RNA as well as free and $\mathrm{pb}$ RNA fractions were isolated, and gene expression was measured by real-time PCR. (A-C) The expression ratio in restimulated versus factor-deprived cells is calculated as a log-2 fold-change for Igbp1 (A), mEd2 (B), and Fli1

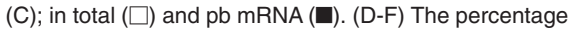
of mRNA associated with polysomes (pb-mRNA) was calculated for the same genes under the different conditions. (G-I) $1 / 11$ cells transduced with an empty control vector $(\boldsymbol{\square})$ or with an elF4E expression vector (elF4E
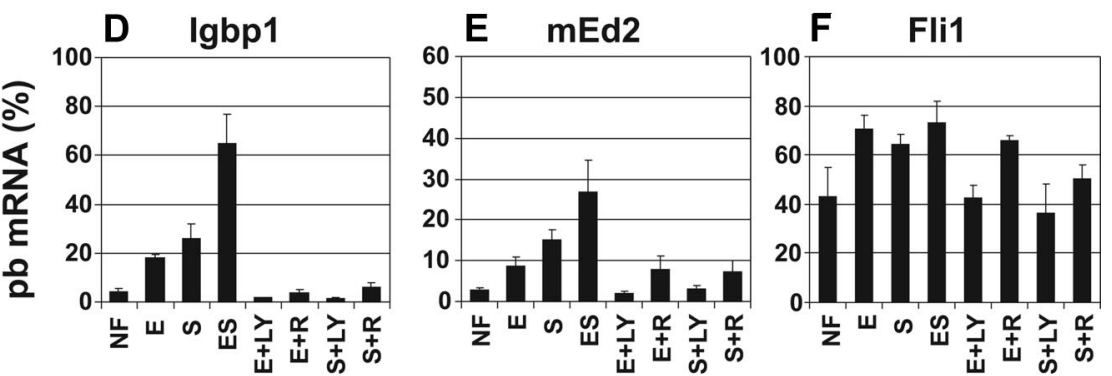
overexpression, $\square$ ) were factor-deprived and restimulated as indicated. The percentage pb mRNA was calculated for Igbp1 (G), mEd2 (H), and Fli1 (I). (J-L) I/11 cells were induced to differentiate and total RNA was isolated before (t0) and 24 (t24), 48 (t48), and 72 hours (t72) after differentiation induction. The expression ratio in differentiated vs nondifferentiated cells was calculated as a log-2 fold-change for lgbp1 (J), $m E d 2(\mathrm{~K})$, and Nfe2 (L). Error bars were calculated from 4 independent measurements using 2 different RNA batches.
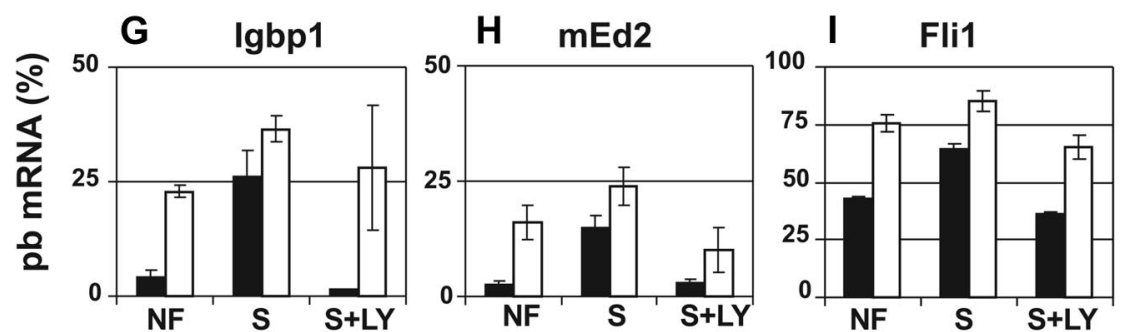

a empty vector $\square$ elF4E overexpression
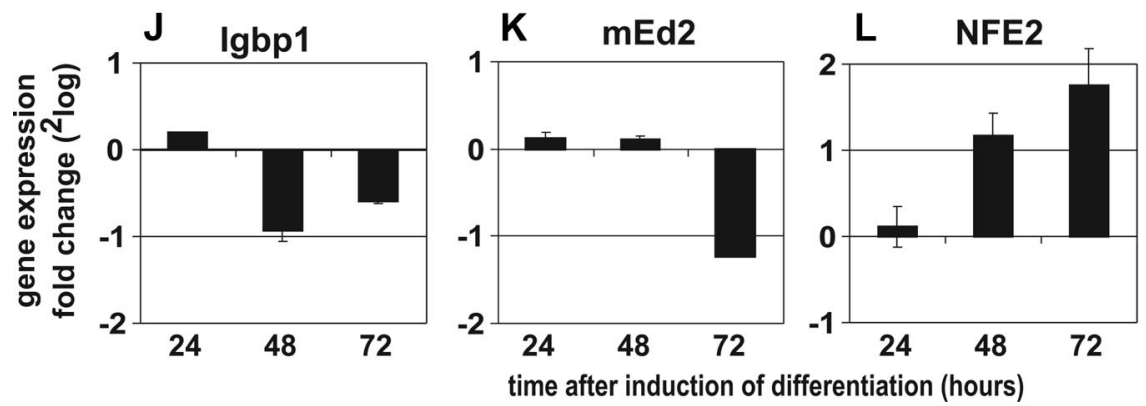

Overexpression of eIF4E is expected to render the selected transcripts less sensitive to Epo/SCF-induced PI3K activity. ${ }^{10}$ Indeed, polysome recruitment of all transcripts became partially factor independent in cells overexpressing eIF4E (Table 1 and Figure 2G,H; for cells, see Blazquez-Domingo et al ${ }^{10}$ ). Effects in the Fli-1 controls were again maximally 2-fold (Figure 2I).

We previously showed that PI3K activity is required for the expansion of erythroblast cultures. Overexpression of eIF4E rendered cells independent of PI3K activation and impaired differentiation. ${ }^{2,10}$ Therefore, proteins whose expression is controlled by PI3K- and eIF4E-dependent mRNA polysome recruitment are expected to be required during erythroblast proliferation. pb mRNA was isolated from I/11 cells induced to differentiate, and Q-PCR showed that the selected genes were all down-regulated during differentiation (Table 1; Figure 2J,K). The erythroid transcrip- tion factor $N f e 2$ is known to be up-regulated during differentiation and is shown as a control (Figure 2L).

In conclusion, translation of 10 of 11 transcripts selected from 83 genes subject to Epo/SCF-induced polysome recruitment (Igbpl, mEd2, Rnf138, Nap1l1, Cnih, Nubp1, Uhmk1, Hnrpal, Nm23-M2, and $Y b x l)$ was strictly controlled by the PI3K-mTOR-eIF4E pathway.

\section{Epo/SCF-dependent protein expression of Igbp1 and Uhmk1}

The high-density complexes with which the transcripts associated in response to PI3K activation and eIF4E expression are assumed to be polysomes. Potentially, however, these could represent high-density hnRNP complexes. To examine whether the association of transcripts in high-density complexes reflects protein expression, we analyzed protein expression of Igbp1 and Uhmk1 
on Western blot and compared it with factor-dependent protein expression of Fli-1. In contrast to Fli-1, expression of Igbp1 and Uhmk1 was more sensitive to inhibition of translation compared with inhibition of transcription (Figure S2). Restimulation of factor-deprived erythroblasts with Epo and SCF rapidly increased Igbp1 and Uhmk1 protein expression, which was inhibited by rapamycin and CHX. Fli-1 expression, however, was inhibited by $\mathrm{CHX}$, but not by rapamycin (Figure S2). Igbp1 protein expression was also enhanced in cells constitutively expressing eIF4E (Figure S5). Thus, factor-dependent Igbp1 and Uhmk1 protein expression was appropriately reflected by RNA present in high-density polysomes.

\section{Functional analysis of target genes}

Because SCF-induced activation of the PI3K-mTOR-eIF4E pathway sustains expansion and delays differentiation of erythroblast cultures, we investigated the functional role of the proteins requiring this pathway for their expression. From the 8 selected genes that showed PI3K-dependent polysome recruitment, 7 were expressed from retroviral expression vectors downstream of a myc-epitope tag (introducing the ORFs without the UTRs that control translation; for unclear reasons, Nubpl resisted cloning in pBabe). Expression of selected genes in Phoenix cells was checked on Western blots, and correct cellular distribution of these proteins was assessed by immunofluorescence (Figure S3). The expression vectors were transduced into I/11 cells, and single cell-derived clones were established, generating empty vector control clones in every respective experiment.

With 4 of the 7 genes (Uhmk1, Cnih, Rnf138, and Nap1l1), we repeatedly failed to establish I/11 clones stably expressing these genes despite proper transient expression in Phoenix cells. Hnrpal, Igbpl, and $m E d 2$ (2010315L10Rik) were expressed in Phoenix and I/11 cells, and several single cell-derived I/11 clones were established (Figure S4 and data not shown). To analyze if and to what extent these 3 proteins mimic SCF-induced suppression of differentiation, clones positive for exogenous protein expression were subjected to differentiation conditions (Epo plus iron-loaded transferrin). Differentiation parameters, including cell number, mean cell volume, hemoglobin per cell volume, and cell morphology, were analyzed at various time points (Figure 3; and data not shown). On induction of differentiation, empty vector-transduced control cells showed the expected transient proliferation $(\sim 3$ divisions within 48 hours) and hemoglobin accumulation (Figure 3A), accompanied by size decrease and a predominantly mature normoblast/ erythrocyte morphology (Figure 3D). Constitutive expression of Hnrpal yielded similar results as empty vector (data not shown), whereas expression of $I g b p 1$ and $m E d 2$ impaired differentiation. Erythroblasts constitutively expressing Igbpl proliferated exponentially for more than 72 hours, remained large, hardly accumulated hemoglobin, and maintained a blast-like morphology (Figure $3 \mathrm{~B}, \mathrm{D})$. Erythroblasts constitutively expressing $m E d 2$ were partially impaired in differentiation; the cells became smaller but did not accumulate hemoglobin and showed a partially differentiated morphology (Figure 3C,D). In these experiments, we used the $m E d 2$ ORF published to enhance an ERK-dependent reporter construct (PM26). ${ }^{42}$ We also expressed a longer cDNA, recently described to encode the novel Q-SNARE protein D12 (Use1) in Phoenix cells. ${ }^{43}$ The intracellular localization of D12 was similar to $\mathrm{mEd} 2$, but we failed to express the D12 protein in I/11 cells, suggesting that the truncated protein inhibits differentiation, whereas the full-length protein seems incompatible with erythroblast proliferation.
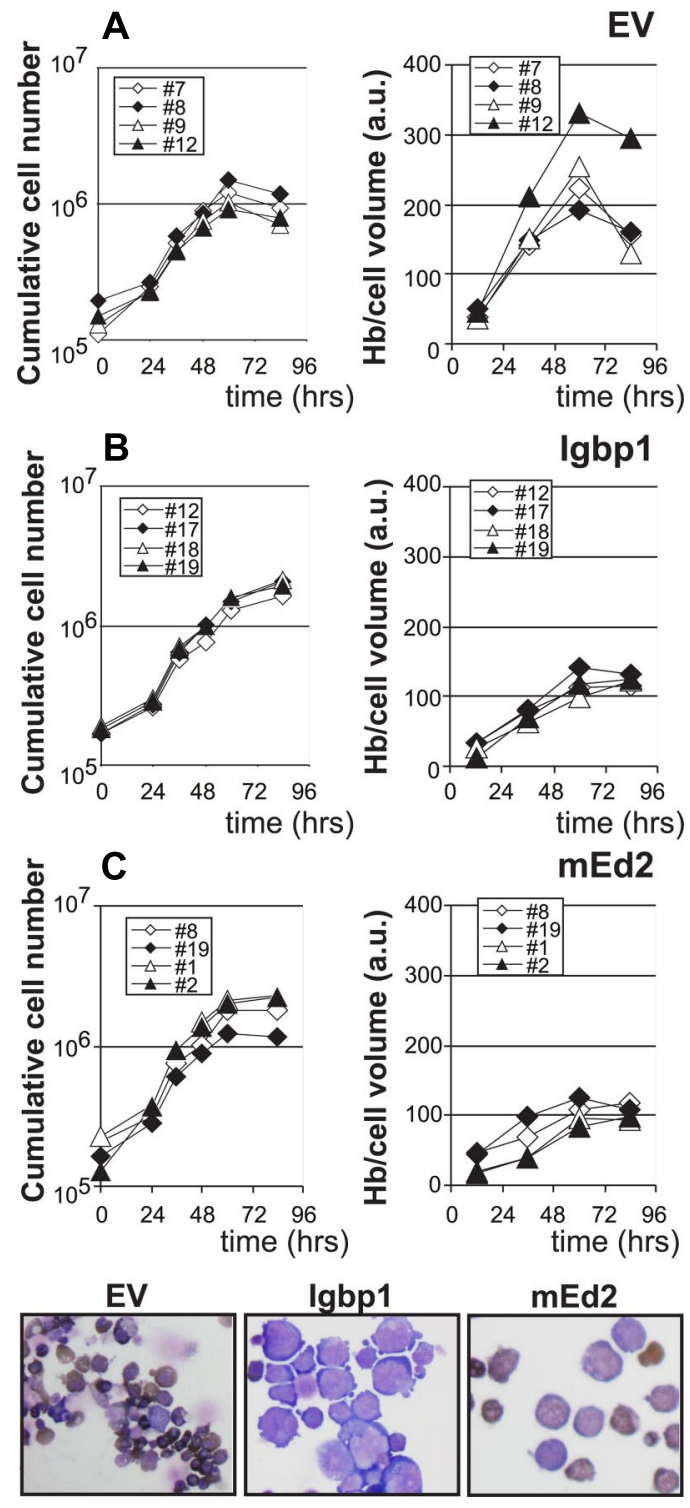

Igbp1

mEd2
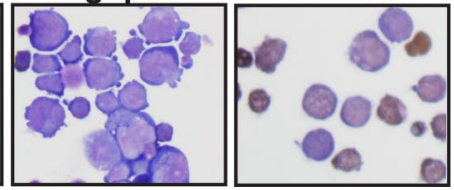

Figure 3. Overexpression of Igbp1 and $m E d 2$ impairs differentiation of $1 / 11$ erythroid progenitors. $1 / 11$ cells transduced with an empty vector (EV; A) or Igbp1 (B) or mEd2 (C) expression vectors were seeded in differentiation medium. Four single-cell-derived clones for each construct were analyzed at regular intervals during 4 days. Cumulative cell numbers (left panels) and hemoglobin content per cell volume (arbitrary units [a.u.], right panels) were measured. (D) At day 3 , cells were harvested for cytospins and stained for hemoglobin (brown) and histologic dyes. Hemoglobinized and enucleated erythrocytes are abundant in control cells, whereas Igbp1-and mEd2-expressing cells contain mainly blasts.

Transforming growth factor- $\beta$ (TGF- $\beta$ ) counteracts the effect of SCF and enhances differentiation of erythroblasts in presence of Epo plus SCF (H.B., M.v.L., unpublished data, June 2000). Therefore, we examined whether TGF- $\beta$ could induce differentiation of cells constitutively expressing Igbp1. In the presence of Epo plus SCF, the constitutive expression of Igbp1 in I/11 cells enhanced proliferation (Figure 4A,B), completely prevented the slow size decrease seen in control cells, and fully inhibited hemoglobin accumulation and morphologic maturation (Figure $4 \mathrm{C}-\mathrm{G})$. As expected, addition of TGF- $\beta$ inhibited proliferation and accelerated differentiation of control cells (Fig 4A,C,E). TGF- $\beta$ also induced differentiation in Igbp1 expressing erythroblasts but to a much lesser extent. Compared with control cells, the addition of TGF- $\beta$ to the Igbp1 expressing cells showed delayed onset of inhibition of proliferation (day 5 instead of day 2), size decrease 

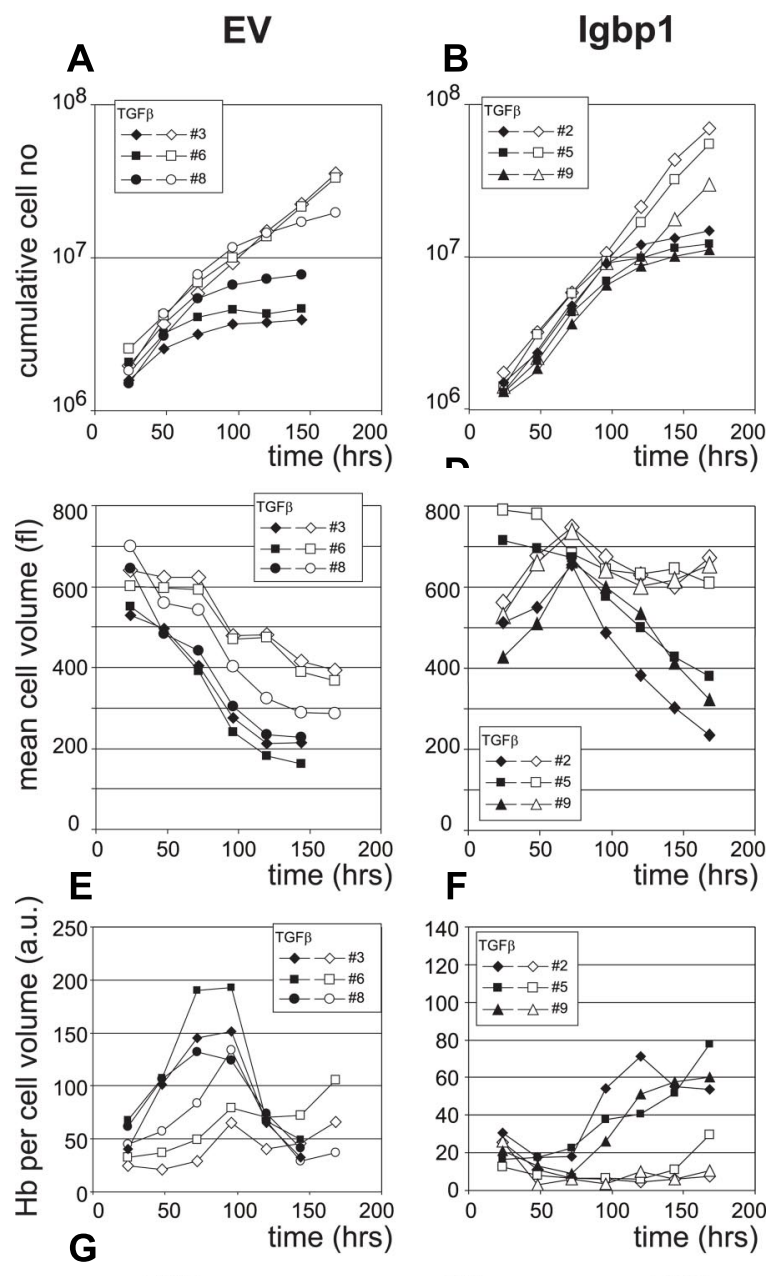

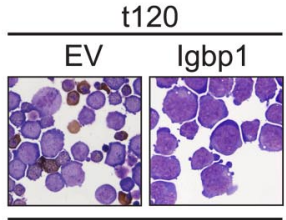

no TGF $\beta$

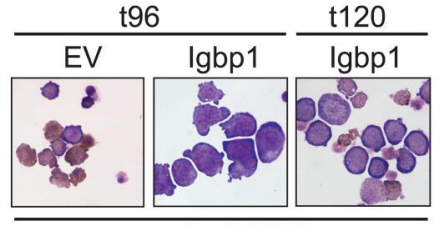

plus TGF $\beta$
Figure 4. Igbp1 expression delays and impedes TGF- $\beta$-induced differentiation in Epo/SCF-treated erythroblasts. Three clones transduced with empty vector (EV; $\mathrm{A}, \mathrm{C}, \mathrm{E})$ or Igbp1 expression constructs (Igbp1; B,D,F) were cultured in the presence of Epo and SCF but without Dex, supplemented (black symbols) or not supplemented (white symbols) with $20 \mathrm{ng} / \mathrm{mL}$ of TGF- $\beta$. Cumulative cell numbers $(A, B)$, mean cell volume $(C, D)$, hemoglobin per cell volume $(E, F)$, and cell morphology $(G)$ were examined at day 4 (t96) or 5 (t120) after differentiation induction. (See also legend to Figure 3).

(day 4 instead of day 1), and hemoglobinization (maximal at day 7-8 instead of day 3-4; Figure 4B,D,F). In line with this, TGF- $\beta-$ treated Igbp 1 expressing erythroblasts were still largely immature at the time (t96), whereas most control cells were in an advanced state of maturation (small and hemoglobinized, Figure 4G). In conclusion, TGF- $\beta$ induced only a limited differentiation in Igbp1-expressing cells, which suggests that Igbp1 may interfere with aspects of TGF- $\beta$ signaling.

\section{Igbp1 affects 4EBP and p70S6k phosphorylation}

Igbp1 associates with the serine/threonine phosphatase Pp2a to modulate Pp2a phosphatase activity toward its different targets. ${ }^{26,28}$ Among these targets are 4EBP and p70S6k. ${ }^{44,45}$ We analyzed Epoand SCF-induced phosphorylation of 4EBP and p70S6k in Igbp1-
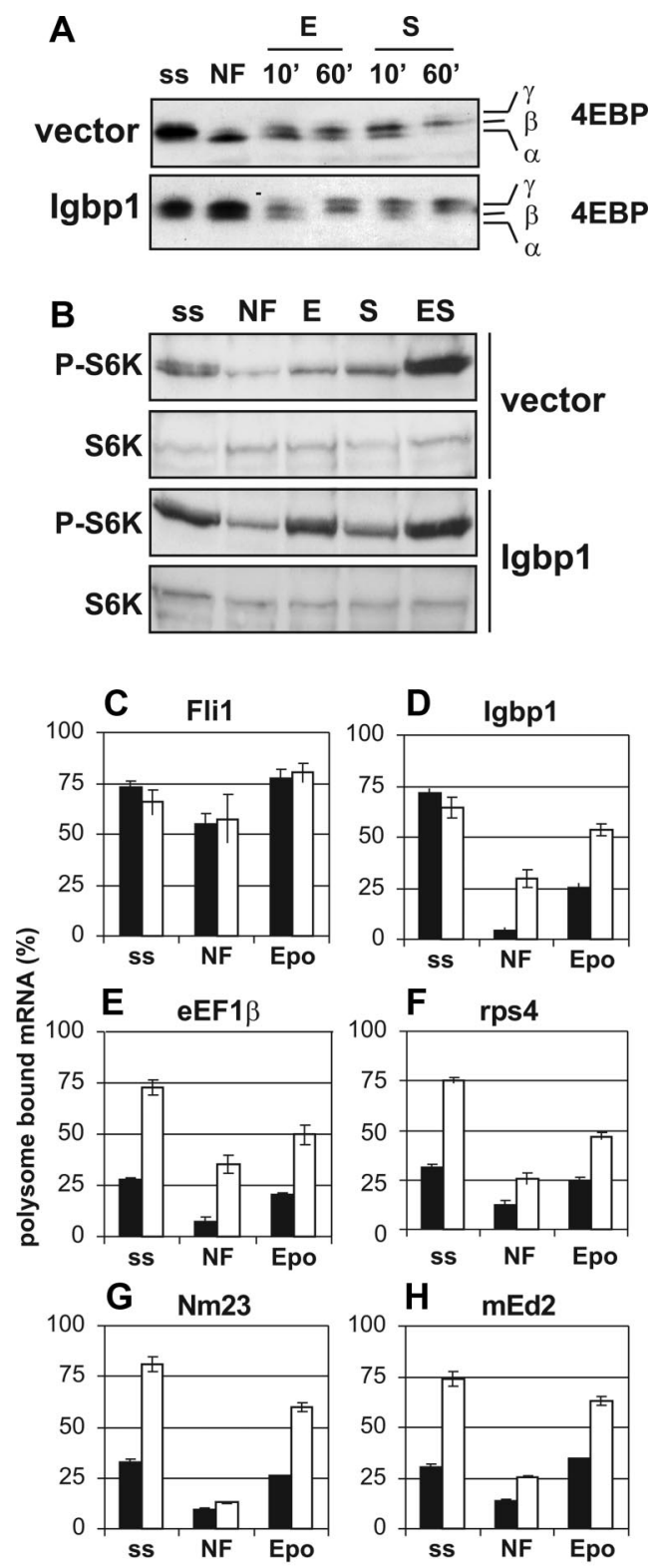

- empty vector $\square$ Constitutive Igbp1 expression

Figure 5. Constitutive Igbp1 expression increases phosphorylation of 4EBP and S6K and enhances Epo-induced polysome recruitment of structured transcripts. $(A, B) l / 11$ cells transduced with an empty control vector (vector) or with an Igbp1 expression vector were factor-deprived (4 hours), stimulated with Epo (E, $5 \mathrm{U} / \mathrm{mL}$ ), SCF (S, $100 \mathrm{ng} / \mathrm{mL}$ ), or Epo plus SCF (ES), or left untreated (NF). Expanding $\mathrm{I} / 11$ cells in the presence of Epo, SCF, and dexamethasone are steady state (ss). (A) Western blots from total cell lysates were stained with antibodies recognizing total 4EBP (4EBP $\mathrm{Ab}$ ). The nonphosphorylated, hypophosphorylated, and hyperphosphorylated proteins can be discriminated by their distinct electrophoretic mobility as $\alpha, \beta$, and $\gamma$ isoforms, respectively. (B) Western blots from samples stimulated as indicated for 10 minutes were stained with a phospho-specific antibody against p70S6K (P-S6K) and counterstained for total S6K to control for equal loading. (C-H) Expanding I/11 empty vector control cells $(\square)$ or cells constitutively expressing Igbp1 $(\square)$ were factor-deprived and left untreated (NF) or restimulated with erythropoietin (Epo, $2 \mathrm{U} / \mathrm{mL} ; 2$ hours). Free and polysome-bound mRNA was isolated and assayed for the expression of Fli-1 (C), Igbp1 (D), eEF1 $\beta$ (E), rps4 $(\mathrm{F}), \operatorname{Nm23}(\mathrm{G})$, and $m E d 2(\mathrm{H})$. The percentage of mRNA associated with polysomes (pb-mRNA) was calculated for the different genes under the different conditions. Constitutive lgbp1 expression enhances polysome recruitment of translationally controlled transcripts in response to Epo alone.

expressing I/11 cells and respective control cells. As previously shown, SCF but not Epo induced full phosphorylation of 4EBP. ${ }^{10}$ On constitutive expression of Igbp1, however, stimulation of 
erythroblasts by Epo was sufficient to induce hyperphosphorylation of 4EBP (Figure 5A). Phosphorylation of p70S6k required the presence of both Epo and SCF in control cells. Interestingly, constitutive expression of Igbp1 increased Epo-induced phosphorylation of p70S6k to levels obtained only with Epo plus SCF but did not enhance SCF-induced phosphorylation of p70S6k (Figure $5 \mathrm{~B})$. Apparently, the activation of p70S6K requires at least 2 cooperating pathways: SCF-induced activation of Igbp1 plus an Igbpl independent pathway activated by Epo. The enhanced phosphorylation of 4E-BP and p70S6 $\mathrm{k}$ in Igbp1-expressing cells in the presence of Epo is in line with enhanced proliferation and impaired differentiation of Igbp1-expressing erythroblasts in the presence of Epo only.

\section{Constitutive expression of $\alpha 4$ enhances polysome recruitment of elF4E-sensitive mRNAs}

Next we tested whether constitutive expression of Igbp1 also enhances translation of transcripts previously found to depend on increased levels of free eIF4E. Expression levels of various genes were measured by Q-PCR in subpolysomal and pb mRNA fractions isolated from empty vector control erythroblasts and erythroblasts constitutively expressing Igbp1. Polysome recruitment of Igbp1 itself was increased on factor deprivation and Epo restimulation (Figure 5D), which is expected as the expressed construct lacks the regulatory sequences responsible for factor-dependent translation. Polysome recruitment of Fli-1, which is not subject to factordependent translation, is not affected by Igbp1 expression (Figure 5C). However, 2 transcripts with a terminal oligopyrimidine tract, eIF $1 \beta$ and $R p s 4$, as well as 2 transcripts with a highly structured 5'UTR, $m E d 2$ and Nm23-M2, show increased polysome recruitment, both during steady-state expansion and after Epo stimulation (Figure 5E-H). Together, these data indicate that translational control of Igbp1 is an important positive feedback signal to enhance polysome recruitment of eIF4E-sensitive mRNAs.

\section{Discussion}

Activation of the PI3K-mTOR-eIF4E pathway is an important mechanism by which SCF delays differentiation and sustains proliferation of erythroblasts. ${ }^{10}$ This suggests that selective polysome recruitment of eIF4E-sensitive mRNAs is crucial to erythropoiesis. In this study, we identified a unique set of genes that are hardly regulated at the level of gene transcription but depend on SCF-induced, PI3K-dependent increase in eIF4F complexes to be recruited to polysomes. Functional analysis revealed that constitutive expression of one of these genes, Immunoglobulin binding protein 1 (Igbpl, also known as the $\alpha 4$ subunit of Pp2a), strongly impaired terminal differentiation of erythroblasts. Constitutive expression of Igbp1 maintained phosphorylation of 4EBP and p70S6K in the presence of Epo to levels otherwise only obtained in presence of SCF. Igbp1 appeared to function in a positive feedback loop of mTOR-regulated polysome recruitment of eIF4E-sensitive mRNAs (Figure 6). Our data emphasize the important role of selective polysome recruitment in control of gene expression and cell fate determination.

\section{Specific transcripts recruited to polysomes by SCF signaling}

We show that polysome-bound mRNA profiling, integrating gene expression control at the level of transcription, mRNA nuclear export, and polysome recruitment, ${ }^{46,47}$ allowed the identification of

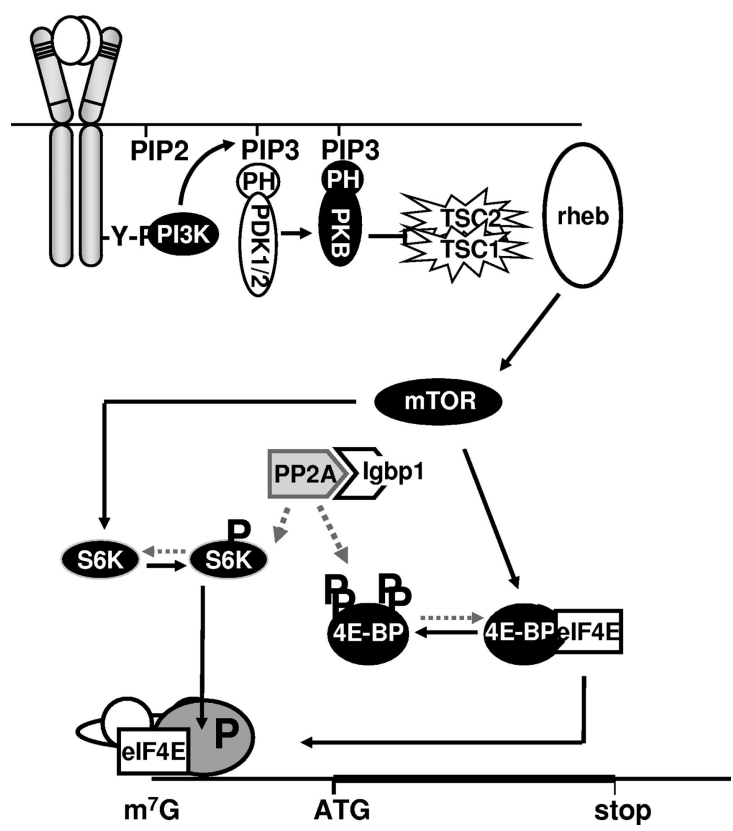

Figure 6. Activation of $\mathrm{PI} 3 \mathrm{~K}$ is essential for proliferation of erythroblasts. Activated phosphotidylinositol-3 kinase (PI3K) generates phosphatidylinositol (3,4,5triphosphate (PIP3), which serves as an anchor for multiple $\mathrm{PH}$-domain containing proteins, such as phosphoinositide-dependent kinase 1 and 2 (PDK1/2) transducing signals to the protein kinase $B$ (PKB) pathway. PKB activates mammalian target of rapamycin (mTOR) through phosphorylation of the tumor suppressor complex Tsc1/Tsc2 (tuberous sclerosis protein), which releases RAS-homolog enriched in brain (Rheb). Activation of mTOR results in phosphorylation and activation of p70S6 kinase $(\mathrm{S} 6 \mathrm{~K}),{ }^{13}$ and hierarchical phosphorylation of $4 \mathrm{E}$-binding protein (4EBP), resulting in release of the mRNA cap-binding factor eukaryotic initiation factor $4 \mathrm{E}$ (elF4E). Subsequently, elF4E can bind the scaffold protein elF4G, which enables the formation of the elF4F scanning complex at the cap (methyl-7-guanidine; $m^{7} G$ ) of transcripts. Igbp 1 has the capacity to sequester the catalytic domain of $\mathrm{Pp} 2 \mathrm{a}\left(\mathrm{Pp} 2 \mathrm{a}_{\mathrm{c}}\right.$ ), preventing dephosphorylation of both $4 \mathrm{EBP}$ and $\mathrm{p} 70 \mathrm{~S} 6 \mathrm{~K}$, resulting in enhanced translation initiation efficiency.

multiple genes that were regulated specifically at the level of polysome recruitment via Epo/SCF signaling and would not be detected by standard mRNA profiling. One of these genes, Igbpl, was critically involved in regulating erythroid progenitor renewal versus differentiation. This indicates that polysome recruitment is an important level at which signaling-dependent gene expression regulates erythropoiesis. Rajasekhar et al demonstrated PI3K- and Mek1-dependent, selective polysome recruitment of mRNA in v-Ras/v-Akt transformed glioblastoma cells. ${ }^{48}$ Others identified transcripts that are specifically recruited to polysomes on overexpression of eIF4E in mouse embryo fibroblasts ${ }^{49}$ or in human epithelial cells. ${ }^{50}$ We found little overlap between genes identified in our studies because of differences in cell type and experimental approach. Notably, overexpression of eIF4E improved polysome recruitment of, eg, Nm23-M2 and Igbp1 in absence of PI3K activity, but not to levels obtained by full stimulation with Epo/SCF. This suggests that polysome recruitment of the targets identified in our screen may depend on additional mechanisms that the other screens did not select for. Together, however, screens using polysome-bound bound mRNA indicate that regulation of gene expression at the translational level is an important mechanism in development and cancer. ${ }^{51,52}$

\section{Selective polysome recruitment depends on UTR elements}

SCF signaling stimulates cap-dependent translation and is expected to identify transcripts that require increased levels of the eIF4F 
complex. It is broadly accepted that these transcripts are characterized by structured $5^{\prime}$ UTRs. ${ }^{22,31}$ Our list of translationally regulated genes contained ribosomal proteins and some translation factors assumed to contain a TOP sequence ${ }^{53}$ (Rps10, Rpl10a, Rpl18, Rpl26, Rpl36, and eIF3s12 in cluster 1; Rps5, Rps16, Rpl22l1 and $R p l 27 a$ in cluster 5; Table S5). Many other ribosomal proteins, however, failed to pass the thresholds we set for signalingdependent polysome recruitment, suggesting that a TOP sequence alone fails to impose strong, signal-regulated translational control on a transcript. The genes selected for functional analysis lacked a TOP sequence, but other structural RNA motifs that contribute to control of translation initiation are difficult to recognize. Most of such structured 5' UTRs are incompletely represented in the databases because structures hamper reverse transcription. Even knowledge of the correct 5' UTR does not always allow for recognition of the structural configuration that controls polysome recruitment, examples being the stem-loop iron response element ${ }^{54}$ or the consensus pseudoknot structure bound by Fragile-X mental retardation protein (Frm1). ${ }^{55}$ Besides such structures, upstream AUGs (uAUG) may affect polysome recruitment because translation of upstream open reading frames (uORF) can modulate translation of the proper ORF. ${ }^{56,57}$ We have been able to elongate the 5'UTR of Igbpl, $m E d 2$, and Nm23-M2 beyond the reported cDNA start, using RACE experiments at increased temperatures to facilitate melting of secondary structure, and detected potential stem-loop structures and uAUGs in these genes (A. Nieradka, G.G., M.v.L., unpublished data, December 2006).

\section{The role of Igbp1 in erythropoiesis}

The activity of the central regulator of protein synthesis, mTOR, is modulated by a variety of signals. ${ }^{18}$ Polysome recruitment of transcripts that require activation of the $\mathrm{PI} 3 \mathrm{~K} / \mathrm{mTOR} / \mathrm{eIF} 4 \mathrm{E}$ pathway are sensitive not only to SCF but also to amino acid starvation and lack of cAMP. ${ }^{58,59}$ The serine/threonine phosphatase Pp2a is one of the potential antagonist of mTOR. ${ }^{60}$ Functional Pp2a consists of a catalytic subunit $\left(\mathrm{Pp} 2 \mathrm{a}_{\mathrm{C}}\right)$, a structural subunit $\left(\mathrm{Pp} 2 \mathrm{a}_{\mathrm{A}}\right)$, and a variable regulatory subunit $\left(\mathrm{Pp} 2 \mathrm{a}_{\mathrm{B}}\right){ }^{61,62}$ One of these regulatory subunits is Igbp1, also known as $\alpha 4$. The interaction of Pp2a with Igbp1 was shown to inhibit its activity toward 4EBP and p70S6K, ${ }^{44,45}$ but Pp2a activity on other targets is enhanced. ${ }^{30} \mathrm{Pp} 2 \mathrm{a}$ has been implied in mTOR-regulated polysome recruitment as addition of rapamycin disrupts the Pp2a/Igbp1 complex, ${ }^{26}$ changing the constitution of the $\mathrm{Pp} 2 \mathrm{a}$ trimeric protein. ${ }^{63}$ However, most of these studies used ectopic expression studies, factor-independent cell lines, or otherwise nonphysiologic conditions. We showed here that constitutive expression of Igbp1, similar to addition of SCF, potently attenuated and delayed differentiation of erythroblasts in the presence of Epo. Igbp1 binds and regulates Pp2a and may prevent dephosphorylation of both 4EBP and p70S6K as described, ${ }^{44,45}$ which stimulates polysome recruitment of respective signal regulated transcripts important for erythropoiesis. This is supported by the following observations: (1) Constitutive Igbp1 expression enhances phosphorylation of 4EBP and p70S6K in presence of Epo to levels normally reached by Epo plus SCF (Figure 5A,B). (2) TGF- $\beta$ is not able to induce differentiation of Igbp1 expressing I/11 cells. TGF- $\beta$ induces association of the catalytic subunit of $\mathrm{Pp} 2 \mathrm{a}\left(\mathrm{Pp} 2 \mathrm{a}_{\mathrm{C}}\right)$ with a different regulatory subunit (Ppp2r5a or $\mathrm{B} \alpha$ ) that stabilizes a complex containing Pp2a and p70S6K, in which p70S6K is dephosphorylated and inhibited. ${ }^{64}$ Activation of both the Smad pathway and Pp2a is required for TGF- $\beta$-induced inhibition of proliferation. ${ }^{64}$ Increased expression of Igbp1 is expected to counteract the TGF- $\beta$-mediated activation of $\mathrm{Pp} 2 \mathrm{a}$ by sequestering $\mathrm{Pp} 2 \mathrm{a}_{\mathrm{C}}$, maintaining $\mathrm{p} 70 \mathrm{~S} 6 \mathrm{~K}$ activity in the presence of TGF- $\beta$. This could explain why Igbp1 expression counteracts TGF- $\beta$-induced differentiation of SCFtreated erythroblasts. (3) Polysome recruitment of previously identified genes is enhanced by constitutive Igbp1 expression (similar to eIF4E overexpression; Figure S5). This suggests that SCF-induced expression of Igbp 1 causes positive feedback in polysome recruitment of multiple eIF4E-sensitive mRNAs, some of which could contribute to attenuation of erythroid differentiation. In line with this, another inhibitor of $\mathrm{Pp} 2 \mathrm{a}$, the putative oncogene SET, ${ }^{65}$ is induced in CML, ${ }^{66}$ perhaps contributing to differentiation arrest of the leukemic cells.

It is important to note, however, that $\mathrm{Pp} 2 \mathrm{~A}$ is a very general phosphatase and that Igbp1 may control multiple cellular processes in addition to phosphorylation of 4EBP and $\mathrm{p} 70$ $\mathrm{S} 6 \mathrm{~K},{ }^{30}$ whereas, on the other hand, Igbp1 only modulates a part of all cellular Pp2a (70 regulatory subunits are known to date $\left.{ }^{61,62}\right)$. Lack of Igbp 1 results in very early embryonal lethality, ${ }^{28}$ and knockdown of Igbp 1 would not give any insight into its importance in control of mRNA translation.

\section{Genes regulated by selective polysome recruitment and their tumorigenic potential}

Whereas Igbp 1 and $\mathrm{mEd} 2$ could only be expressed at restricted levels in erythroblasts, and 4 other selected genes could not be expressed at all, Hnrpa1 could be constitutively expressed at abundant levels without altering the erythroblast phenotype. Hnrpa1 is involved in the generation of correct splice variants of the erythrocyte membrane protein Band4.1, ${ }^{67,68}$ and incorrect splicing has major consequences in vivo that may not become apparent in vitro. ${ }^{69}$ With respect to the proteins resisting expression, there may be a need to express them at precisely regulated levels or only during a specific phase of the cell cycle. Notably, these genes included Uhmkl/Kis and Cnih, which associate with and control stability of tubulins during mitosis. ${ }^{70,71} \mathrm{Rnf} 138$ contains ubiquitin ligase and nuclear localization domains. Its constitutive expression may result in degradation of essential nuclear proteins. $\mathrm{mEd} 2$ is also known as MAPK-activating protein PM26, ${ }^{42}$ and its human homolog is uncharacterised hematopoietic stem/progenitor cells protein MDS032. Recently, mEd2 was shown to be a Q-SNARE protein, termed D12 or Use1, involved in endoplasmic reticulum (ER) trafficking. ${ }^{43,72}$ Interestingly, reduced expression of D12 resulted in increased phosphorylation of eIF2a. This opens the interesting possibility that mEd2-dependent surveillance of protein quality in the ER may also cause feedback from eIF4E activation to polysome recruitment of $\mathrm{mEd} 2$ and subsequent protection of eIF $2 \mathrm{a}$ from inactivation by phosphorylation.

Constitutive activation of PI3K has frequently been found in both solid tumors and leukemia. ${ }^{73-78}$ The strong inhibition of erythroid differentiation by overexpression of eIF4E or by constitutive expression of Igbp1, and the high levels of eIF4E found in several cancer types ${ }^{31}$ indicate that regulation of mRNA translation is a critical event in carcinogenesis downstream of PI3K. Currently, rapamycin homologs are tested as anticancer drugs in a large variety of tumors, yielding promising results. ${ }^{79-81}$ Although it is generally assumed that the anticancer effect of rapamycin and its analogs is the result of a general inhibition of protein synthesis in proliferating cells, it is more likely that inhibition of mTOR specifically targets structured mRNAs. Control of translation not only regulates cell growth to reach "start" in the cell cycle but also 
is an important and selective mechanism to regulate gene expression. However, many translationally controlled genes await further characterization with respect to regulation and function.

\section{Acknowledgments}

The authors thank Dr Victor de Jager for assistance with the Rosetta Resolver software; Dr Ivo Touw for many fruitful discussions and critical reading of the manuscript; Liu Wing for technical assistance; Drs Peter Seither, Andreas Weith (Boehringer Ingelheim, Biberach, Germany), Helmuth Dolznig, Thomas Waerner, and Sandra Pilat (IMP, Vienna, Austria) for mRNA profiling of erythroblasts, of which the complete data will be published elsewhere; Dr Bart Aarts (Erasmus MC, Rotterdam, The Netherlands) for assistance in confocal scanning microscopy; Dr David Brautigan (University of Virginia, Charlottesville) for anti-Igbp1 antibodies; Dr Manfred Boehm (National Institutes of Health/National Heart, Lung, and Blood Institute, Bethesda, MD) for anti-Uhmk1 antibodies; and Ortho-Biotech (Tilburg, The Netherlands) for their kind gift of Eprex (erythropoietin).
This work was supported by grants from the European Union (Brussels, Belgium; HPRN-CT-2000-00 083; MRTN-CT-2004005499), The Netherlands Organisation for Scientific Research (Den Haag, The Netherlands; 050-10-051), the Dutch Cancer Society/KWF (Amsterdam, The Netherlands; EUR 2000-2230), and the Austrian Science Foundation, FWF (Vienna, Austria; SFB-F28; H.B., E.W.M.).

\section{Authorship}

Contribution: G.G. and M.v.L. designed and performed most of the research and drafted the paper. M.B.-D., A.K., W.J.B., E.W.M., and H.B. designed and/or performed the expression profiling.

Conflict-of-interest disclosure: The authors declare no competing financial interests.

Correspondence: Marieke von Lindern, Department Hematology, Erasmus MC, PO Box 1738, 3000 DR Rotterdam, The Netherlands; e-mail: m.vonlindern@erasmusmc.nl.

\section{References}

1. Dolznig H, Boulme F, Stangl K, et al. Establishment of normal, terminally differentiating mouse erythroid progenitors: molecular characterization by cDNA arrays. FASEB J. 2001;15:1442-1444.

2. von Lindern M, Deiner EM, Dolznig H, et al. Leukemic transformation of normal murine erythroid progenitors: v- and c-ErbB act through signaling pathways activated by the EpoR and c-Kit in stress erythropoiesis. Oncogene. 2001;20:36513664.

3. Bauer A, Tronche F, Wessely O, et al. The glucocorticoid receptor is required for stress erythropoiesis. Genes Dev. 1999;13:2996-3002.

4. Broudy VC, Lin NL, Priestley GV, Nocka K, Wolf NS. Interaction of stem cell factor and its receptor c-kit mediates lodgment and acute expansion of hematopoietic cells in the murine spleen. Blood. 1996;88:75-81.

5. Klingmuller U, Wu H, Hsiao JG, et al. Identification of a novel pathway important for proliferation and differentiation of primary erythroid progenitors. Proc Natl Acad Sci U S A. 1997;94:30163021.

6. Sui X, Krantz SB, Zhao ZJ. Stem cell factor and erythropoietin inhibit apoptosis of human erythroid progenitor cells through different signalling pathways. Br J Haematol. 2000;110:63-70.

7. Nishigaki K, Hanson C, Ohashi T, Thompson D, Muszynski K, Ruscetti S. Erythroid cells rendered erythropoietin independent by infection with Friend spleen focus-forming virus show constitutive activation of phosphatidylinositol 3-kinase and Akt kinase: involvement of insulin receptor substrate-related adapter proteins. J Virol. 2000; 74:3037-3045.

8. Haseyama Y, Sawada K, Oda A, et al. Phosphatidylinositol 3-kinase is involved in the protection of primary cultured human erythroid precursor cells from apoptosis. Blood. 1999;94:1568-1577.

9. Bakker WJ, Blazquez-Domingo M, Kolbus A, et al. FoxO3a regulates erythroid differentiation and induces BTG1, an activator of protein arginine methyl transferase 1. J Cell Biol. 2004;164:175184.

10. Blazquez-Domingo $M$, Grech $G$, von Lindern $M$. Translation initiation factor $4 \mathrm{E}$ inhibits differentiation of erythroid progenitors. Mol Cell Biol. 2005; 25:8496-8506.

11. Tee AR, Manning BD, Roux PP, Cantley LC, Blenis J. Tuberous sclerosis complex gene prod- ucts, Tuberin and Hamartin, control mTOR signaling by acting as a GTPase-activating protein complex toward Rheb. Curr Biol. 2003;13:12591268.

12. Inoki K, Li Y, Xu T, Guan KL. Rheb GTPase is a direct target of TSC2 GAP activity and regulates mTOR signaling. Genes Dev. 2003;17:18291834.

13. Dufner A, Thomas G. Ribosomal S6 kinase signaling and the control of translation. Exp Cell Res. 1999;253:100-109.

14. Gingras AC, Gygi SP, Raught B, et al. Regulation of 4E-BP1 phosphorylation: a novel two-step mechanism. Genes Dev. 1999;13:1422-1437.

15. Holz MK, Ballif BA, Gygi SP, Blenis J. mTOR and S6K1 mediate assembly of the translation preinitiation complex through dynamic protein interchange and ordered phosphorylation events. Cell. 2005;123:569-580.

16. Gingras AC, Raught B, Sonenberg N. Regulation of translation initiation by FRAP/mTOR. Genes Dev. 2001;15:807-826.

17. Gingras AC, Raught B, Sonenberg N. elF4 initiation factors: effectors of mRNA recruitment to ribosomes and regulators of translation. Annu Rev Biochem. 1999;68:913-963.

18. Proud CG. Signalling to translation: how signal transduction pathways control the protein synthetic machinery. Biochem J. 2007;403:217-234.

19. Kozak M. A second look at cellular mRNA sequences said to function as internal ribosome entry sites. Nucleic Acids Res. 2005;33:6593-6602.

20. Duncan R, Milburn SC, Hershey JW. Regulated phosphorylation and low abundance of HeLa cell initiation factor elF-4F suggest a role in translational control: heat shock effects on elF-4F. J Biol Chem. 1987;262:380-388.

21. Sonenberg N, Gingras A-C. The mRNA 5'-binding protein elF4E and control of cell growth. Curr Opin Cell Biol. 1998;10:268-275.

22. Koromilas AE, Lazaris-Karatzas A, Sonenberg N. mRNAs containing extensive secondary structure in their $5^{\prime}$ noncoding region translate efficiently in cells overexpressing initiation factor elF-4E. EMBO J. 1992;11:4153-4158.

23. Jefferies HB, Fumagalli S, Dennis PB, Reinhard C, Pearson RB, Thomas G. Rapamycin suppresses 5'TOP mRNA translation through inhibition of p70s6k. EMBO J. 1997;16:3693-3704.

24. Wang $X$, Beugnet A, Murakami M, Yamanaka S,
Proud CG. Distinct signaling events downstream of mTOR cooperate to mediate the effects of amino acids and insulin on initiation factor $4 \mathrm{E}$ binding proteins. Mol Cell Biol. 2005;25:25582572.

25. Murata K, Wu J, Brautigan DL. B cell receptorassociated protein alpha4 displays rapamycinsensitive binding directly to the catalytic subunit of protein phosphatase 2A. Proc Natl Acad Sci U S A. 1997;94:10624-10629.

26. Inui S, Sanjo H, Maeda K, Yamamoto H, Miyamoto E, Sakaguchi N. Ig receptor binding protein 1 (alpha4) is associated with a rapamycinsensitive signal transduction in lymphocytes through direct binding to the catalytic subunit of protein phosphatase 2A. Blood. 1998;92:539546.

27. Di Como CJ, Arndt KT. Nutrients, via the Tor proteins, stimulate the association of Tap42 with type 2A phosphatases. Genes Dev. 1996;10:19041916.

28. Kong M, Fox CJ, Mu J, et al. The PP2Aassociated protein alpha4 is an essential inhibitor of apoptosis. Science. 2004;306:695-698.

29. Prickett TD, Brautigan DL. The alpha4 regulatory subunit exerts opposing allosteric effects on protein phosphatases PP6 and PP2A. J Biol Chem. 2006;281:30503-30511.

30. Liu J, Prickett TD, Elliott E, Meroni G, Brautigan DL. Phosphorylation and microtubule association of the Opitz syndrome protein mid-1 is regulated by protein phosphatase $2 \mathrm{~A}$ via binding to the regulatory subunit alpha 4. Proc Natl Acad Sci U S A. 2001;98:6650-6655.

31. De Benedetti A, Graff JR. elF-4E expression and its role in malignancies and metastases. Oncogene. 2004;23:3189-3199.

32. De Benedetti A, Harris AL. elF4E expression in tumors: its possible role in progression of malignancies. Int J Biochem Cell Biol. 1999;31:59-72.

33. Topisirovic I, Guzman ML, McConnell MJ, et al. Aberrant eukaryotic translation initiation factor 4E-dependent mRNA transport impedes hematopoietic differentiation and contributes to leukemogenesis. Mol Cell Biol. 2003;23:8992-9002.

34. Bader AG, Vogt PK. An essential role for protein synthesis in oncogenic cellular transformation. Oncogene. 2004;23:3145-3150.

35. Kowenz E, Leutz A, Doderlein G, Graf T, Beug H. ts-oncogene-transformed erythroleukemic cells: a 
novel test system for purifying and characterizing avian erythroid growth factors. In: Neth R, Gallo RC, Greaves MF, Kabisch H, eds. Modern Trends in Human Leukemia VII. Vol. 31. Heidelberg, Germany: Springer Verlag; 1987:199-209.

36. Beug $\mathrm{H}$, Palmieri S, Freudenstein $\mathrm{C}$, Zentgraf $\mathrm{H}$, Graf T. Hormone-dependent terminal differentiation in vitro of chicken erythroleukemia cells transformed by ts mutants of avian erythroblastosis virus. Cell. 1982;28:907-919.

37. Weng L, Dai H, Zhan $Y, H e Y$, Stepaniants SB Bassett DE. Rosetta error model for gene expression analysis. Bioinformatics. 2006;22:1111-1121.

38. van Dijk TB, van Den Akker E, Amelsvoort MP, Mano H, Lowenberg B, von Lindern M. Stem cell factor induces phosphatidylinositol 3 '-kinasedependent Lyn/Tec/Dok-1 complex formation in hematopoietic cells. Blood. 2000;96:3406-3413.

39. Joosten M, Blazquez-Domingo M, Lindeboom F et al. Translational control of putative protooncogene Nm23-M2 by cytokines via phosphoinositide 3-kinase signaling. J Biol Chem. 2004;279: 38169-38176.

40. Kolbus A, Blazquez-Domingo M, Carotta S, et al. Cooperative signaling between cytokine receptors and the glucocorticoid receptor in the expansion of erythroid progenitors: molecular analysis by expression profiling. Blood. 2003;102:31363146

41. Schmidt $U$, van den Akker E, Parren-van Amelsvoort M, et al. Btk is required for an efficien response to erythropoietin and for SCF-controlled protection against TRAIL in erythroid progenitors. J Exp Med. 2004;199:785-795.

42. Matsuda A, Suzuki $Y$, Honda G, et al. Large-scale identification and characterization of human genes that activate NF-kappaB and MAPK signaling pathways. Oncogene. 2003;22:3307-3318.

43. Okumura AJ, Hatsuzawa K, Tamura T, et al. Involvement of a novel Q-SNARE, D12, in quality control of the endomembrane system. J Biol Chem. 2006;281:4495-4506.

44. Bishop JD, Nien WL, Dauphinee SM, Too CK. Prolactin activates mammalian target-ofrapamycin through phosphatidylinositol 3-kinase and stimulates phosphorylation of $\mathrm{p} 70 \mathrm{~S} 6 \mathrm{~K}$ and 4E-binding protein-1 in lymphoma cells. J Endocrinol. 2006;190:307-312.

45. Peterson RT, Desai BN, Hardwick JS, Schreiber SL. Protein phosphatase 2A interacts with the $70-\mathrm{kDa}$ S6 kinase and is activated by inhibition of FKBP12-rapamycinassociated protein. Proc Natl Acad Sci U S A. 1999:96:4438-4442.

46. Pradet-Balade B, Boulme F, Beug H, Mullner EW, Garcia-Sanz JA. Translation control: bridging the gap between genomics and proteomics? Trends Biochem Sci. 2001:26:225-229.

47. Grolleau A, Bowman J, Pradet-Balade B, et al. Global and specific translational control by rapamycin in T cells uncovered by microarrays and proteomics. J Biol Chem. 2002;277:2217522184.

48. Rajasekhar VK, Viale A, Socci ND, Wiedmann M, Hu X, Holland EC. Oncogenic Ras and Akt signaling contribute to glioblastoma formation by differential recruitment of existing mRNAs to polysomes. Mol Cell. 2003;12:889-901.

49. Mamane $Y$, Petroulakis E, Martineau $Y$, et al. Epigenetic activation of a subset of mRNAs by elF4E explains its effects on cell proliferation. PLoS ONE. 2007;2:e242.

50. Larsson O, Li S, Issaenko OA, et al. Eukaryotic translation initiation factor $4 \mathrm{E}$ induced progression of primary human mammary epithelial cells along the cancer pathway is associated with targeted translational deregulation of oncogenic drivers and inhibitors. Cancer Res. 2007;67: 6814-6824.

51. Waerner T, Alacakaptan M, Tamir I, et al. ILEl: a cytokine essential for EMT, tumor formation, and late events in metastasis in epithelial cells. Cancer Cell. 2006;10:227-239.

52. Provenzani A, Fronza R, Loreni F, Pascale A, Amadio M, Quattrone A. Global alterations in mRNA polysomal recruitment in a cell model of colorectal cancer progression to metastasis. Carcinogenesis. 2006;27:1323-1333.

53. Levy S, Avni D, Hariharan N, Perry RP, Meyuhas O. Oligopyrimidine tract at the $5^{\prime}$ end of mammalian ribosomal protein mRNAs is required for their translational control. Proc Natl Acad Sci U S A. 1991;88:3319-3323.

54. Thomson AM, Rogers JT, Leedman PJ. Ironregulatory proteins, iron-responsive elements and ferritin mRNA translation. Int J Biochem Cell Biol. 1999;31:1139-1152.

55. Darnell JC, Fraser CE, Mostovetsky O, et al. Kissing complex RNAs mediate interaction between the Fragile-X mental retardation protein $\mathrm{KH} 2$ domain and brain polyribosomes. Genes Dev. 2005;19:903-918.

56. Child SJ, Miller MK, Geballe AP. Translational control by an upstream open reading frame in the HER-2/neu transcript. J Biol Chem. 1999;274: 24335-24341.

57. Kozak M. Effects of intercistronic length on the efficiency of reinitiation by eucaryotic ribosomes. Mol Cell Biol. 1987;7:3438-3445

58. Hara K, Yonezawa K, Weng Q-P, Kozlowski MT Belham C, Avruch J. Amino acid sufficiency and mTOR regulate p70 S6 kinase and elF-4E BP1 through a common effector mechanism. J Biol Chem. 1998:273:14484-14494.

59. Lawrence JC Jr, Fadden P, Haystead TA, Lin TA PHAS proteins as mediators of the actions of insulin, growth factors and cAMP on protein synthesis and cell proliferation. Adv Enzyme Regul. 1997;37:239-267.

60. Kloeker S, Reed R, McConnell JL, et al. Parallel purification of three catalytic subunits of the protein serine/threonine phosphatase $2 \mathrm{~A}$ family (PP2A(C), PP4(C), and PP6(C)) and analysis of the interaction of PP2A(C) with alpha4 protein. Protein Expr Purif. 2003;31:19-33.

61. Sontag E. Protein phosphatase 2A: the Trojan Horse of cellular signaling. Cell Signal. 2001;13: 7-16.

62. Yoo SJ, Boylan JM, Brautigan DL, Gruppuso PA. Subunit composition and developmental regulation of hepatic protein phosphatase 2A (PP2A). Arch Biochem Biophys. 2007:461:186-193.

63. Kamibayashi C, Estes R, Lickteig RL, Yang SI, Craft C, Mumby MC. Comparison of heterotrimeric protein phosphatase $2 \mathrm{~A}$ containing differen B subunits. J Biol Chem. 1994;269:20139-20148.

64. Petritsch C, Beug H, Balmain A, Oft M. TGF-beta inhibits p70 S6 kinase via protein phosphatase 2A to induce G1 arrest. Genes Dev. 2000;14: 3093-3101.
65. von Lindern M, van Baal S, Wiegant J, Raap A, Hagemeijer A, Grosveld G. Can, a putative oncogene associated with myeloid leukemogenesis, may be activated by fusion of its $3^{\prime}$ half to different genes: characterization of the set gene. Mol Cell Biol. 1992;12:3346-3355.

66. Neviani P, Santhanam R, Trotta R, et al. The tumor suppressor PP2A is functionally inactivated in blast crisis CML through the inhibitory activity of the BCR/ABL-regulated SET protein. Cancer Cell. 2005;8:355-368.

67. Yang G, Huang SC, Wu JY, Benz EJ Jr. An erythroid differentiation-specific splicing switch in protein 4.1R mediated by the interaction of SF2/ ASF with an exonic splicing enhancer. Blood. 2005;105:2146-2153.

68. Hou VC, Lersch R, Gee SL, et al. Decrease in hnRNP A/B expression during erythropoiesis mediates a pre-mRNA splicing switch. EMBO J. 2002;21:6195-6204

69. Caceres JF, Kornblihtt AR. Alternative splicing multiple control mechanisms and involvement in human disease. Trends Genet. 2002;18:186-193.

70. Maucuer A, Ozon S, Manceau V, et al. KIS is a protein kinase with an RNA recognition motif. J Biol Chem. 1997;272:23151-23156.

71. Roth S, Neuman-Silberberg FS, Barcelo G, Schupbach T. cornichon and the EGF receptor signaling process are necessary for both anteriorposterior and dorsal-ventral pattern formation in Drosophila. Cell. 1995;81:967-978.

72. Duan JZ, Zhang JP, Zhu SX. mED2: a novel gene involved in mouse embryonic development. Yi Chuan Xue Bao. 2006;33:692-701.

73. Neshat MS, Mellinghoff IK, Tran C, et al. Enhanced sensitivity of PTEN-deficient tumors to inhibition of FRAP/mTOR. Proc Natl Acad Sci U S A. 2001;98:10314-10319.

74. Min YH, Eom Jl, Cheong JW, et al. Constitutive phosphorylation of Akt/PKB protein in acute myeloid leukemia: its significance as a prognostic variable. Leukemia. 2003;17:995-997.

75. Grandage VL, Gale RE, Linch DC, Khwaja A. PI3kinase/Akt is constitutively active in primary acute myeloid leukaemia cells and regulates survival and chemoresistance via NF-kappaB, Mapkinase and p53 pathways. Leukemia. 2005;19:586-594.

76. Sujobert $P$, Bardet $V$, Cornillet-Lefebvre $P$, et al. Essential role for the p110delta isoform in phosphoinositide 3-kinase activation and cell proliferation in acute myeloid leukemia. Blood. 2005;106: 1063-1066.

77. Vivanco I, Sawyers CL. The phosphatidylinositol 3-kinase AKT pathway in human cancer. Nat Rev Cancer. 2002;2:489-501.

78. Luo J, Manning BD, Cantley LC. Targeting the PI3K-Akt pathway in human cancer: rationale and promise. Cancer Cell. 2003;4:257-262.

79. Bjornsti MA, Houghton PJ. The TOR pathway: a target for cancer therapy. Nat Rev Cancer. 2004; 4:335-348.

80. Hidalgo M, Rowinsky EK. The rapamycinsensitive signal transduction pathway as a target or cancer therapy. Oncogene. 2000;19:66806686.

81. Panwalkar A, Verstovsek S, Giles FJ. Mammalian target of rapamycin inhibition as therapy for hematologic malignancies. Cancer. 2004;100:657666. 